\title{
Avian Influenza Viruses Detected in Birds in Sub-Saharan Africa: A Systematic Review
}

\author{
Annie Kalonda ${ }^{1,2,3}$ (), Ngonda Saasa ${ }^{2}$, Panji Nkhoma ${ }^{1}{ }^{1}$, Masahiro Kajihara ${ }^{4}$, \\ Hirofumi Sawa ${ }^{2,4}$, Ayato Takada $2,4,5$ (D) and Edgar Simulundu 2,6,*(D) \\ 1 Department of Biomedical Sciences, School of Health Sciences, University of Zambia, Lusaka 10101, Zambia; \\ anniekalonda@gmail.com (A.K.); panjinkhoma@gmail.com (P.N.) \\ 2 Department of Disease Control, School of Veterinary Medicine, University of Zambia, Lusaka 10101, Zambia; \\ nsaasa@gmail.com (N.S.); sawa@czc.hokudai.ac.jp (H.S.); atakada@czc.hokudai.ac.jp (A.T.) \\ 3 Africa Centre of Excellence for Infectious Disease of Humans and Animals, School of Veterinary Medicine, \\ Lusaka 10101, Zambia \\ 4 Research Center for Zoonosis Control, Hokkaido University, Sapporo 001-0020, Japan; \\ kajihara@czc.hokudai.ac.jp \\ 5 Global Station for Zoonosis Control, Global Institution for Collaborative Research and Education (GI-CoRE), \\ Hokkaido University Kita-ku, Sapporo 001-0020, Japan \\ 6 Macha Research Trust, Choma 20100, Zambia \\ * Correspondence: esikabala@yahoo.com; Tel.: +260-977469479
}

Received: 16 August 2020; Accepted: 5 September 2020; Published: 7 September 2020

check for updates

\begin{abstract}
In the recent past, sub-Saharan Africa has not escaped the devastating effects of avian influenza virus (AIV) in poultry and wild birds. This systematic review describes the prevalence, spatiotemporal distribution, and virus subtypes detected in domestic and wild birds for the past two decades (2000-2019). We collected data from three electronic databases, PubMed, SpringerLink electronic journals and African Journals Online, using the Preferred Reporting Items for Systematic reviews and Meta-Analyses protocol. A total of 1656 articles were reviewed, from which 68 were selected. An overall prevalence of 3.0\% AIV in birds was observed. The prevalence varied between regions and ranged from $1.1 \%$ to $7.1 \%$. The Kruskal-Wallis and Wilcoxon signed-rank sum test showed no significant difference in the prevalence of AIV across regions, $\chi^{2}(3)=5.237, p=0.1553$ and seasons, $\mathrm{T}=820, \mathrm{z}=-1.244, p=0.2136$. Nineteen hemagglutinin/neuraminidase subtype combinations were detected during the reviewed period, with southern Africa recording more diverse AIV subtypes than other regions. The most detected subtype was H5N1, followed by H9N2, H5N2, H5N8 and H6N2. Whilst these predominant subtypes were mostly detected in domestic poultry, H1N6, H3N6, H4N6, H4N8, H9N1 and H11N9 were exclusively detected in wild birds. Meanwhile, $\mathrm{H} 5 \mathrm{~N} 1, \mathrm{H} 5 \mathrm{~N} 2$ and H5N8 were detected in both wild and domestic birds suggesting circulation of these subtypes among wild and domestic birds. Our findings provide critical information on the eco-epidemiology of AIVs that can be used to improve surveillance strategies for the prevention and control of avian influenza in sub-Saharan Africa.
\end{abstract}

Keywords: Orthomyxoviridae; avian influenza; avian influenza virus; subtype; ecology; epidemiology; poultry; wild waterfowl; sub-Saharan Africa

\section{Introduction}

Avian influenza is an acute and highly infectious viral disease caused by influenza A viruses (IAVs) of the genus Alphainfluenzavirus, family Orthomyxoviridae. Avian influenza viruses (AIVs) are important zoonotic pathogens that may cause high morbidity and mortality resulting in substantial economic losses to the poultry industry [1-3]. Migratory avian species within the orders Anseriformes 
(ducks, geese and swans) and Charadriiformes (gulls, terns and shorebirds) are known to be the natural reservoirs of IAVs [4,5]. While IAVs are principally found in wild aquatic birds, they infect other mammalian species such as humans, horses, pigs, cats, dogs, seals and whales among others [6,7]. Moreover, an IAV-like virus has recently been discovered in bats [8,9], suggesting a possible new natural reservoir host.

IAVs are enveloped, single-stranded, negative-sense RNA viruses with a segmented genome. Eight segments of the IAV genome encode up to 18 proteins: polymerase basic 1 (PB1), polymerase basic 2 (PB2), polymerase acid (PA), hemagglutinin (HA), nucleoprotein (NP), neuraminidase (NA), matrix 1 (M), matrix 2 (M2), nonstructural (NS1), nuclear export protein (NS2/NEP), PB1-F2, PB1-N40, PA-X, M42, PA-N155, PA-182, NS3 and PB2-S1 [10-24]. The HA and NA proteins are surface glycoproteins, essential for virus infectivity, and are used in the classification of IAVs into subtypes. Currently, 18 HA and 11 NA subtypes of IAV have been identified, of which 16 HA (H1-H16) and 9 NA (N1-N9) are maintained up to now in avian species [25,26], while 2 HA (H17-H18) and 2 NA (N10-N11) were found in bats [9]. However, some IAV strains have been known to be maintained in mammalian hosts, for example, H1N1 and H3N2 circulate seasonally in humans [27]. Additionally, the HA and NA proteins have the highest evolutionary rates of all influenza virus proteins, which contributes to the genetic and antigenic diversity of these viruses. The genetic diversity is mainly due to two mechanisms, antigenic drift and shift, which involve the accumulation of point mutations over time and the exchange of genome segments between two or more influenza viruses (i.e., genetic reassortment), respectively [28]. These two mechanisms may lead to the emergence of novel strains of IAVs with zoonotic and pandemic potential, which may pose a challenge for control [29].

AIVs can be classified based on their pathogenicity or virulence in chickens as either highly pathogenic avian influenza (HPAI) or low pathogenic avian influenza (LPAI) viruses. The HPAI viruses often become highly pathogenic through the acquisition of multiple basic amino acid residues at the HA cleavage site and are restricted to two subtypes $\mathrm{H} 5$ and $\mathrm{H} 7$ [30]. However, not all $\mathrm{H} 5$ or $\mathrm{H} 7$ viruses have the capacity to become HPAI viruses [31,32]. Outbreaks of HPAI viruses constitute a substantial risk to human health, the poultry industry and the global economy [33]. Since the first detection of H5N1 HPAI viruses in Asia, the viruses have spread throughout the world leading to multiple outbreaks affecting millions of birds and considerable human infections [34-36]. Moreover, in March 2013, H7N9 LPAI virus emerged in eastern China and caused high morbidity and mortality in humans with an overall case fatality ratio of approximately 37\% [37,38]. Furthermore, IAVs have caused at least four major pandemics (1918 "Spanish flu", 1957 "Asian flu", 1968 "Hong Kong flu" and the 2009 "swine flu") in the human population from the 20th century to date, with the worst being the 1918 "Spanish flu" H1N1 pandemic, which recorded nearly 500 million cases and 50 million human deaths globally $[39,40]$. Although LPAI viruses have typically been known to cause inapparent infections in poultry, some subtypes have caused severe clinical signs in poultry, such as the H9N2 LPAI virus, which has been reported to cause respiratory disease, a reduction in egg production and mortality in birds [41,42].

The importance of poultry farming in sub-Saharan Africa cannot be overemphasized as it is one of the most rapidly growing sectors and an important source of protein and income for several rural households in the region [43]. In Africa, poultry numbers have been estimated to be approximately 1.1 billion $[44,45]$. Despite the growth of poultry production in the region, the birds are usually reared under poor biosecurity measures, which provide the ideal setting for zoonotic transmission of AIVs [46]. It is also worthy to note that sub-Saharan Africa is a seasonal shelter for a large number of migratory aquatic birds that make their seasonal movements between the temperate zone and the tropics [47], with approximately 5.4 million ducks that gather during the northern winter [48]. These birds congregate and mix with the indigenous water birds in their overwintering sites, which provides opportunities for dissemination and transmission of AIVs between different populations and continents [48]. 
Despite several studies documenting the presence and impact of AIVs in sub-Saharan Africa [48-54], there is a lack of consolidated data on the eco-epidemiology of these viruses in birds in the region. Therefore, in this review, we aimed at systematically integrating data from different studies within the region to provide the prevalence, spatiotemporal distribution and virus subtypes detected in domestic and wild birds from January 2000 to December 2019.

\section{Materials and Methods}

\subsection{Literature Search and Data Collection}

To systematically review the literature, we followed the Preferred Reporting Items for Systematic Reviews and Meta-Analyses (PRISMA) protocol 2010 guidelines (S1 Checklist) [55]. Inclusion and exclusion criteria were defined in terms of the relevance of the articles to achieve the study objectives.

A systematic literature search was conducted to identify all publications reporting the detection of avian influenza virus in birds in sub-Saharan Africa between 2000 and 2019. Three electronic databases namely PubMed, SpringerLink electronic journals and African Journals Online (AJOL) were searched using the medical subject headings (MeSH) keywords and Boolean connectors. The following keywords were used: "influenza in birds," "influenza," "birds," "avian," "avian influenza," "avian influenza virus," "sub-Saharan Africa," "countries in sub-Saharan Africa," "epidemiology," "prevalence" and "subtype." Furthermore, the search was restricted to original articles, titles, abstracts and keywords published in English, which reported on AIVs using serological and/or molecular methods. The last search was conducted on 17th January 2020. All references located in the searches were entered into Endnote, a web-based reference manager. Furthermore, a database was built that included the references of all selected publications, as well as the title, author, year of publication, country or countries where the study was conducted and language of publication. The articles were selected using a two-stage approach. During the first stage, the publications were selected based on their titles and abstracts. During the second stage, the full text of articles selected in the first stage was assessed for eligibility. At this point, the articles that did not meet the inclusion criteria were excluded.

\subsection{Inclusion Criteria}

All study designs were included in this review except experimental studies as these do not represent natural infections. Additionally, studies published between 2000 and 2019, serological, molecular and both serological and molecular studies on AIV in birds in sub-Saharan Africa were investigated. All AIV subtypes and avian species from which the virus was detected were included in this review. Additionally, publications containing data on the positive diagnostic test result, data on incidence, prevalence and distribution of avian influenza in any naturally infected birds were included.

\subsection{Exclusion Criteria}

Studies published before 2000 and after 31st December 2019, editorials, comments/letter to the editor, congress or conference abstracts, review articles, perspectives, personal opinions, theoretical models, pathogenesis models, animal models, case reports in humans, or reports in non-avian species and studies reported in languages other than English were not included. Moreover, studies with the following characteristics were excluded: the diagnostic test not specified, sample source not described, publications reporting data published elsewhere other than sub-Saharan Africa, outbreak reports without laboratory-based confirmation, reporting a zero incidence/prevalence in any diagnostic test, studies with data overlapping with another included study and publications exclusively on the experimental infection. For prevalence and seasonality of AIV analysis, all studies without sampling time, sample size, prevalence or rate were excluded. Additionally, studies with a sample size of less than five were excluded. 


\subsection{Data Extraction}

A database on reference information regarding the author's name, title and year of publication was recorded in the data extraction file. Furthermore, from the included publications, data were extracted on country or countries of study including region, years of sample collection, avian species, the purpose of study, number of samples analyzed, type of samples collected, the diagnostic method(s) used, number of positives and pathogenicity of the AIV subtypes (LPAI or HPAI).

\subsection{Assessment of Quality and Risk Bias of the Included Studies}

To assess the quality and risk of bias of the included studies, the McMaster Critical Review Form-Qualitative Studies (version 2.0) [56] and McMaster Critical Review Form-Quantitative Studies [57] were used.

\subsection{Statistical Analysis}

Data were entered in Microsoft Office Excel 2018 and analyzed using Python 3.7 for Mac. Prevalence and distributions of AIV were reported using descriptive statistics in the form of frequencies, percentages and presented as tables and graphs. Since data were not normally distributed, non-parametric tests such as the Kruskal-Wallis test and Wilcoxon signed-rank sum test were used to determine associations between seasonality, regions and prevalence of AIV. A Pearson correlation was carried out to determine the association between time in years and number of papers published between 2000 and 2019.

\section{Results}

\subsection{Search Results and Study Selection}

During the literature search, PubMed yielded 1313 records, SpringerLink electronic journals had 293 and AJOL showed 50 records, giving a total of 1656 research records. Of the 1656 research records, 678 (40.9\%) were duplicates and were discarded. Using the set inclusion and exclusion criteria, we screened the remaining 978 records following a flow chart (Figure 1). During the screening, 870/978 $(89.0 \%)$ articles were excluded based on their titles and abstracts, while 108 articles were retained. The 108 full-text articles were further screened for eligibility and 40/108 (37.0\%) were excluded, while a total of 68/108 (63.0\%) articles were deemed eligible for inclusion in this systematic review. Table S1 is provided as a Supplemental Material of all included studies.

\subsection{Characteristics of the Included Studies}

The reviewed articles were published between 2000 and 2019, from 22 sub-Saharan African countries. One article (1.5\%) was published between 2000 and 2004, 16 (23.5\%) between 2005 and 2009 , 23 (33.8\%) between 2010 and 2014 and 28 (41.2\%) between 2015 and 2019 (Figure 2).

A Pearson correlation was computed to assess the relationship between years of publication and the numbers of articles published. There was a positive correlation between the two variables $(\mathrm{r}=0.81$, $n=20, p<0.0001)$. This shows that there was a fairly strong positive and significant increase in the number of published articles between the years 2000 to 2019 (Figure 3).

A review of selected publications yielded a total of 83 published records on the presence of avian influenza in sub-Saharan Africa. Most articles (26.8\%) were for studies done in Nigeria followed by those in South Africa (17.1\%) (Figure 4).

Of the articles included in this review, 39 (57.4\%) were surveillance studies, while 29 (42.6\%) were a combination of either case studies or case reports. Additionally, the studies used either molecular, serological or both molecular and serological techniques to detect AIVs in different species of birds. Specifically, 29 (42.6\%) studies employed molecular methods, 12 (17.6\%) applied serological methods and 27 (39.7\%) used both molecular and serological methods. 


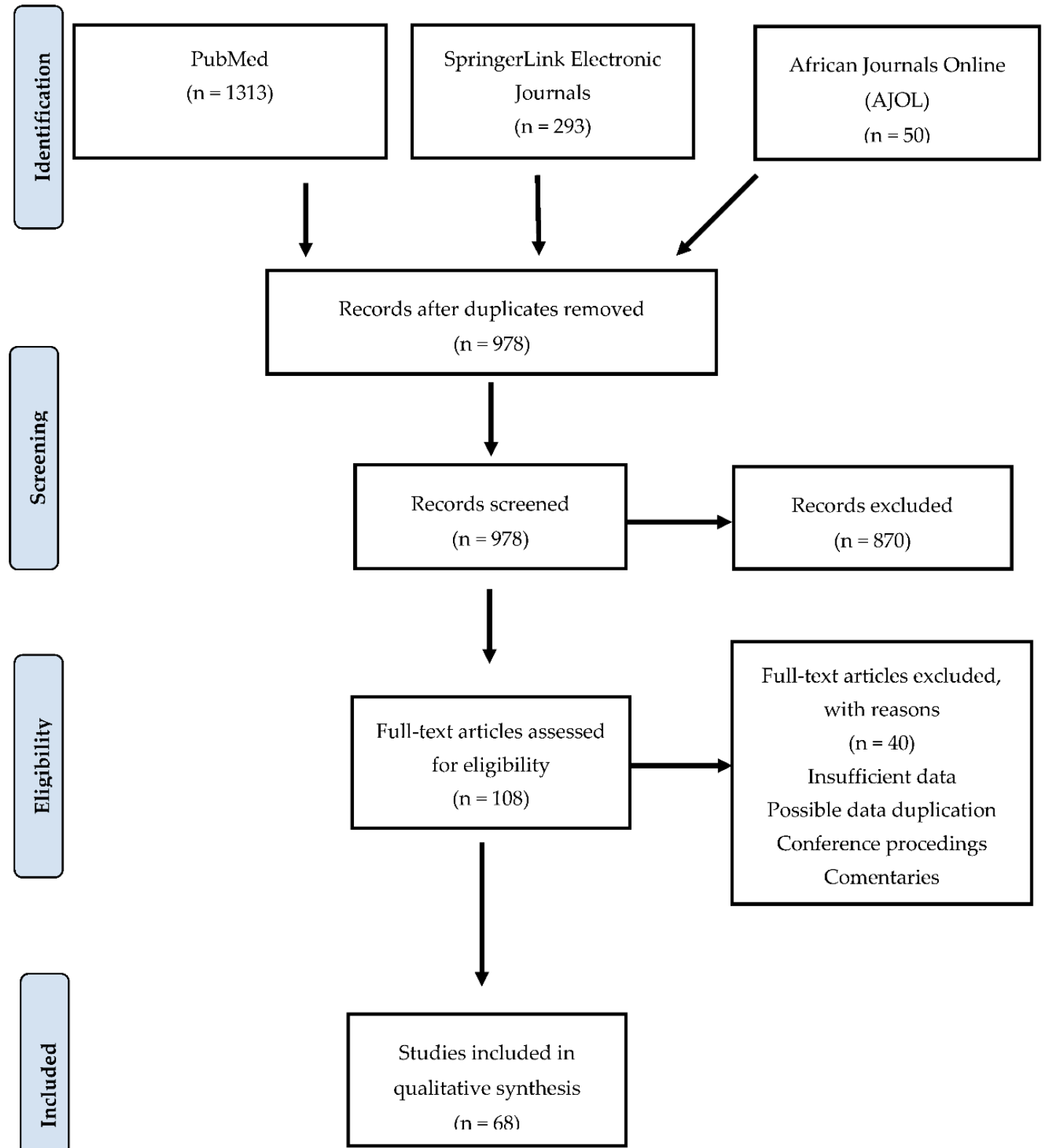

Figure 1. Preferred Reporting Items for Systematic Reviews and Meta-Analyses (PRISMA) flow chart of the literature search, screening, assessing eligibility and article selection.

\subsection{The Prevalence and Seasonality of AIV in Birds in Sub-Saharan Africa}

In many studies, neither prevalence nor sample size was included. Of the 68 studies included in this review, 55 studies with either prevalence values or sample sizes were found. The overall prevalence (determined based on virus isolation and genome detection) and seroprevalence of AIVs and in avian species in sub-Saharan Africa was 3.0\% (Table 1) and 4.1\% (Table 2), respectively. During the analysis, we divided sub-Saharan Africa into regions namely, Central, East, Southern and West Africa for easier analysis and due to their unique seasons of the year. The prevalence varied between regions and ranged from $1.1 \%$ to $7.1 \%$ (Table 1), while seroprevalence ranged from $2.2 \%$ to $4.1 \%$ (Table 2). The majority of the serosurveys were conducted in poultry studies and focused on the detection of $\mathrm{H} 5$ and H7 antibodies. We carried out the Kruskal-Wallis test of independent samples and the Wilcoxon signed rank sum test to determine whether the prevalence distribution of AIV was different across 
seasons and regions in sub-Saharan Africa. Our results showed that there was no significant difference in prevalence across regions $\chi^{2}(3)=5.237, p=0.1553$ and seasons $\mathrm{T}=820, \mathrm{z}=-1.244, p=0.2136$, respectively. However, the highest detection rates of AIVs were observed during the dry season (6.7\%) (that is May to October in Central Africa) (Table 3). The lowest prevalence was obtained in the wet season (0.4\%) (November to April in Central Africa) (Table 3).

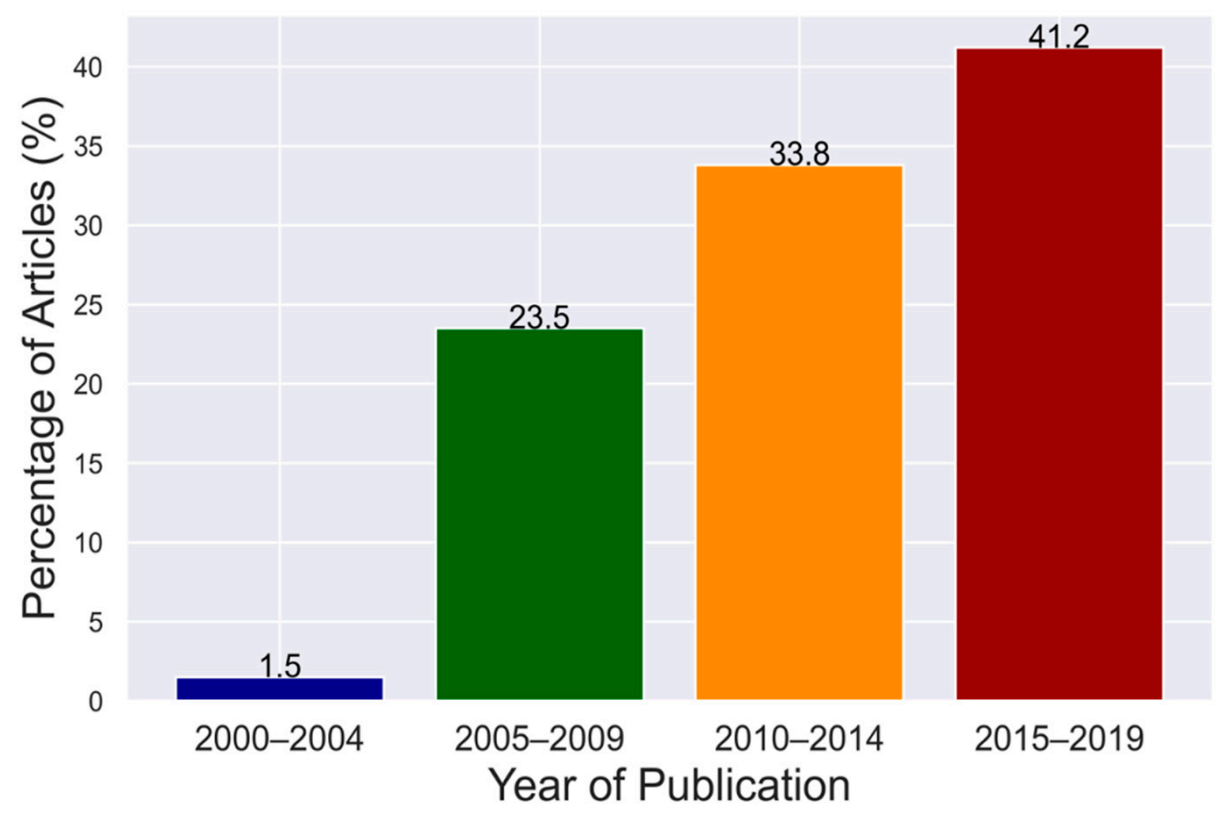

Figure 2. Number of selected articles per quarter from 2000 to 2019.
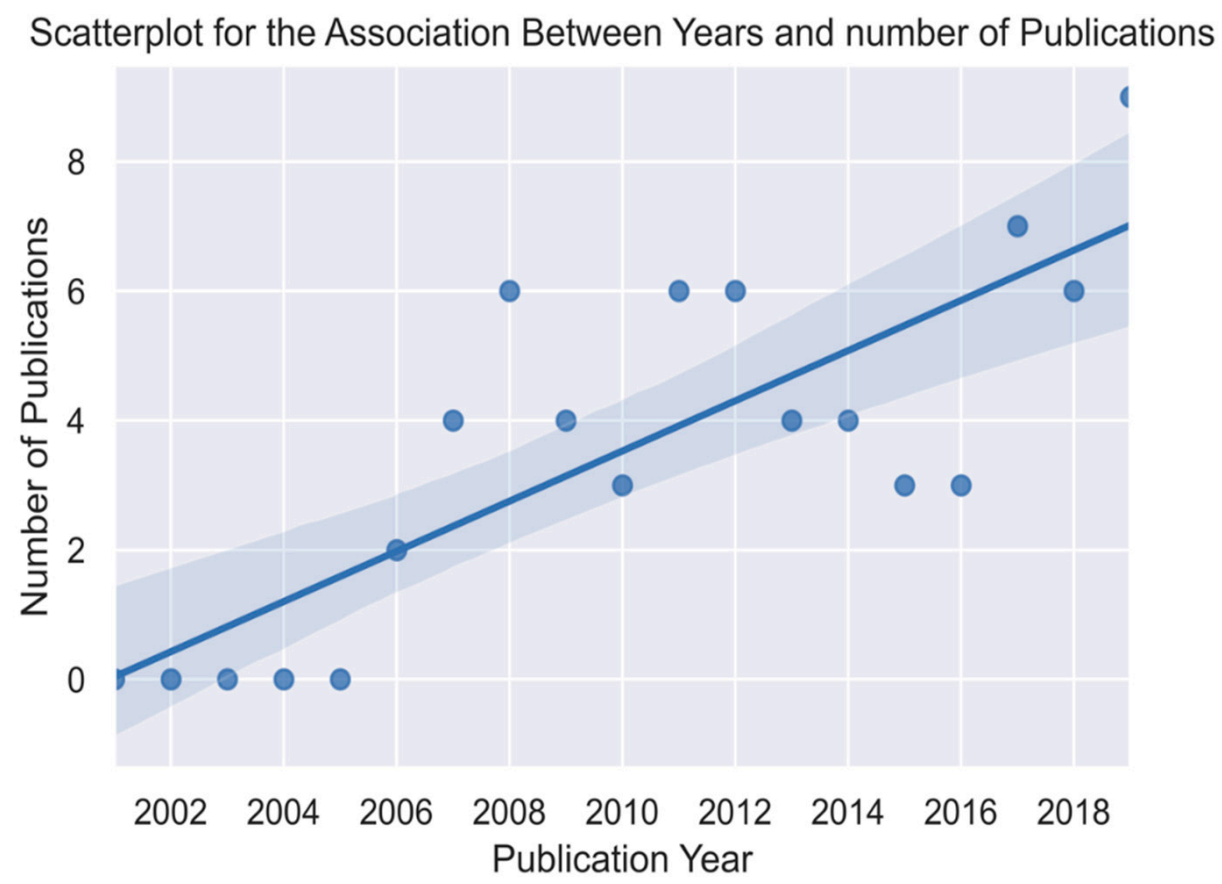

Figure 3. Scatter plot showing the correlation between years and number of publications. 


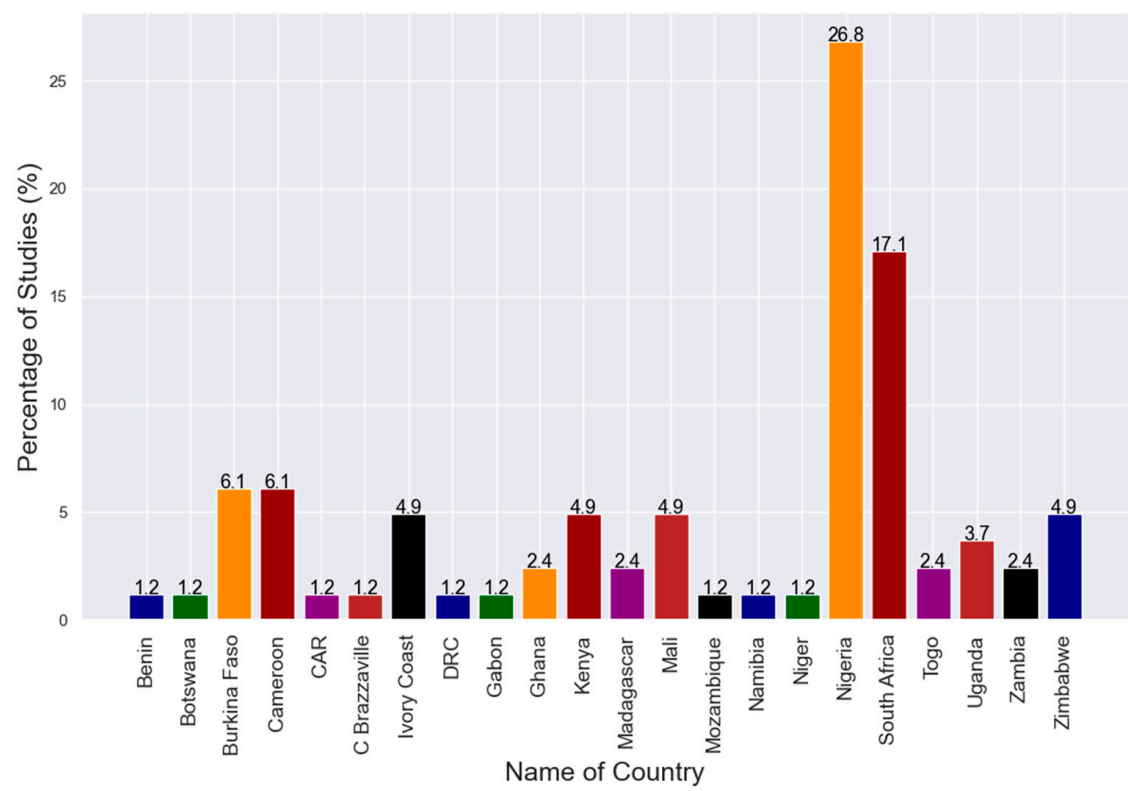

Figure 4. Reviewed articles according to countries.

Table 1. Prevalence of avian influenza virus (AIV) in sub-Saharan Africa.

\begin{tabular}{ccccc}
\hline Study Region & No. of Studies & No. Samples & No. Positive & Prevalence (\%) \\
\hline Central Africa $^{\text {a }}$ & 4 & 4868 & 344 & 7.1 \\
\hline East Africa $^{\mathrm{b}}$ & 6 & 13,875 & 146 & 1.1 \\
\hline West Africa $^{\mathrm{c}}$ & 19 & 38,203 & 1269 & 3.3 \\
\hline Southern Africa $^{\mathrm{d}}$ & 12 & 12,518 & 349 & 2.8 \\
\hline Total & 41 & 69,464 & 2108 & Overall prevalence: 3.0 \\
\hline
\end{tabular}

Study regions: a Central African Republic, Congo Brazzaville, Cameroon and Democratic Republic of Congo,

${ }^{b}$ Kenya, Uganda, ${ }^{c}$ Benin, Burkina Faso, Ivory Coast, Gabon, Ghana, Mali, Niger, Nigeria, Togo, d Botswana,

Namibia, South Africa, Zambia, Zimbabwe.

Table 2. Seroprevalence of AIV in sub-Saharan Africa.

\begin{tabular}{ccccc}
\hline Study Regions & No. of Studies & No. of Samples & No. Samples & Seroprevalence (\%) \\
\hline Central Africa $^{\text {a }}$ & 0 & - & - & - \\
East Africa $^{\mathrm{b}}$ & 2 & 3517 & 77 & 2.2 \\
West Africa $^{\mathrm{c}}$ & 11 & 16,669 & 875 & 5.2 \\
Southern Africa $^{\mathrm{d}}$ & 4 & 235,084 & 9605 & 4.1 \\
Total & 18 & 255,270 & 10,557 & Overall seroprevalence: 4.1 \\
\hline
\end{tabular}

Study regions: ${ }^{a}$ Central African Republic, Congo Brazzaville, Cameroon and Democratic Republic of Congo,

${ }^{b}$ Kenya, Uganda, ${ }^{c}$ Benin, Burkina Faso, Ivory Coast, Gabon, Ghana, Mali, Niger, Nigeria, Togo, d Botswana,

Namibia, South Africa, Zambia, Zimbabwe.

Table 3. Prevalence of AIV according to regions and seasons ${ }^{\mathrm{a}}$.

\begin{tabular}{cccccc}
\hline Study Region & No. of Studies & No. of Samples & Dry Season (\%) & Wet Season (\%) & Reference \\
\hline Central Africa & 4 & 4868 & $325(6.7 \%)$ & $19(0.4 \%)$ & {$[53,58-60]$} \\
East Africa & 5 & 9556 & $71(0.7 \%)$ & $46(0.5 \%)$ & {$[45,61-64]$} \\
West Africa & 18 & 11,680 & $319(2.7 \%)$ & $158(1.4 \%)$ & {$[41,65-81]$} \\
Southern Africa & 11 & 6009 & $165(2.7 \%)$ & $48(0.7 \%)$ & {$[49,51,82-90]$} \\
Total (Overall Prevalence\%) & 38 & 32,113 & $880(2.7 \%)$ & $271(0.8 \%)$ \\
\hline
\end{tabular}

${ }^{a}$ In sub-Saharan Africa, seasons differ according to the regions: Central/Southern Africa-dry season (May-October) and wet season (November-April); East Africa-dry season (January-March/June-October) and wet season (April-June/November-December); West Africa-dry season (January-March/June-October) and wet season (April-June/November-December). 


\subsection{Distribution of the AIV Subtypes and Avian Species}

As depicted in Table 4 and Supplementary Table S2, the included studies reported a diverse range of AIV subtypes in different avian species in the past 20 years. According to the analyzed articles, 52/68 (76.5\%) of studies specified the AIV subtypes, while 16/68 (23.5\%) did not. During the period under review, nine different HA subtypes and six NA subtypes were found in 19 different subtype combinations (Table 4). The 19 AIV subtypes detected were as follows: H1N2, H1N8, H3N6, H3N8, H4N2, H4N6, H4N8, H5N1, H5N2, H5N8, H6N2, H6N8, H7N1, H7N7, H9N1, H9N2, H10N7, H10N9 and H11N9. Southern Africa recorded a wider range of AIV subtype combinations than any other region in sub-Saharan Africa (Table 4). The NA subtypes were not determined for three HA subtypes H5, H6 and H7. Of the 5073 viruses detected, the H5 (78.5\%) subtype was the most common, followed by H9 (2.5\%), H6 (1.4\%), H7 (1.1\%) and the rest falling below $1.0 \%$. The H5Nx and H7Nx were either characterized as LPAI viruses or were not characterized at all (Supplementary Table S2). Overall, the most detected subtype combinations were H5N1, followed by H9N2, H5N2, H5N8 and H6N2. The majority of H5N1 and H5N8 subtypes were HPAI viruses and were commonly detected in domestic poultry especially chicken (Gallus gallus) and domestic ducks (Anas platyrhynchos domestica) (Supplementary Table S2).

Table 4. AIV subtype detection in sub-Saharan Africa according to the included studies.

\begin{tabular}{|c|c|c|c|c|}
\hline Study Region & Central Africa & East Africa & Southern Africa & West Africa \\
\hline HA Subtypes Detected & H5 & H4, H5, H9 & $\begin{array}{c}\text { H1, H3, H4, H5, H6, H7, H9, } \\
\text { H10, H11 }\end{array}$ & H3, H5, H7, H9 \\
\hline $\begin{array}{l}\text { Most Prevalent HA } \\
\text { Subtypes }\end{array}$ & H5 & H5 & $\mathrm{H} 5$ & H5 \\
\hline $\begin{array}{l}\text { HA Subtypes not } \\
\text { Detected }\end{array}$ & H1-H4, H6-H16 & $\begin{array}{l}\mathrm{H} 1-\mathrm{H} 3, \mathrm{H} 6-\mathrm{H} 8 \\
\mathrm{H} 10-\mathrm{H} 16\end{array}$ & H2, H8, H12-H16 & $\begin{array}{c}\mathrm{H} 1-\mathrm{H} 2, \mathrm{H} 4, \mathrm{H} 6, \mathrm{H} 8, \\
\mathrm{H} 10-\mathrm{H} 16\end{array}$ \\
\hline Prevalent NA Subtypes & $\mathrm{N} 1, \mathrm{~N} 8$ & $\mathrm{~N} 2, \mathrm{~N} 6, \mathrm{~N} 8$ & $\mathrm{~N} 1, \mathrm{~N} 2, \mathrm{~N} 6, \mathrm{~N} 7, \mathrm{~N} 8, \mathrm{~N} 9$ & $\mathrm{~N} 1, \mathrm{~N} 2, \mathrm{~N} 7, \mathrm{~N} 8$ \\
\hline $\begin{array}{l}\text { NA Subtypes not } \\
\text { Detected }\end{array}$ & $\begin{array}{c}\text { N2, N3, N4, N5, N6, } \\
\text { N7, N9 }\end{array}$ & $\begin{array}{l}\text { N1, N3, N4, N5, } \\
\text { N7, N9 }\end{array}$ & $\mathrm{N} 3, \mathrm{~N} 4, \mathrm{~N} 5$ & N3, N4, N5, N6, N9 \\
\hline $\begin{array}{l}\text { Prevalent Subtype } \\
\text { Combinations }\end{array}$ & H5N1, H5N8, H5Nx & $\begin{array}{l}\text { H4N6, H5N8, } \\
\text { H9N2, H5Nx }\end{array}$ & $\begin{array}{c}\text { H1N2, H1N8, H3N6, H3N8, } \\
\text { H4N2, H4N6, H4N8, H5N1, } \\
\text { H5N2, H5N8, H6N2, H6N8, } \\
\text { H9N2, H10N7, H10N9, } \\
\text { H11N9, H5Nx, H6Nx, H7Nx }\end{array}$ & $\begin{array}{c}\text { H3N8, H5N1, H5N2, } \\
\text { H7N7, H9N2, H5Nx, } \\
\text { H7Nx }\end{array}$ \\
\hline $\begin{array}{l}\text { Most Prevalent Subtype } \\
\text { Combinations }\end{array}$ & H5N1 & H5N8 & H5N2, H5N8, H6N2 & H5N1, H9N2 \\
\hline
\end{tabular}

Overall, the 52 studies that specified the AIV subtypes recorded both HPAI or LPAI viruses among domestic and wild birds (Supplementary Table S2). Majority of the studies that reported HPAIVs were conducted between 2006-2008 and 2017-2018. Furthermore, the majority of studies that reported HPAIVs were conducted in Nigeria 11 (21.2\%), followed by Burkina Faso and South Africa 4 (7.6\%) each, Cameroon 3 (5.8\%) and 2 (3.8\%) from Cote d'Ivoire. The Democratic Republic of Congo (DRC), Ghana, Niger, Namibia, Togo and Uganda recorded 1 (1.9\%) HPAIV study each. The rest of the studies $22(42.3 \%)$ recorded either LPAIVs or did not specify the pathogenicity of the detected subtype. Zambia and Zimbabwe did not report any HPAIVs according to the 68 studies included in this review (Figure 5). As depicted in Supplementary Table S2, all the HPAIVs from Cameroon, DRC, Ghana, Niger and Togo were only detected in domestic birds, while those from Burkina Faso, Cote d'Ivoire, Nigeria and South Africa were detected in both domestic and wild birds. H5N1, H5N2 and H5N8 HPAI viruses were detected mostly in domestic poultry. Further, the H5N2 HPAI virus was more common among ostriches (Struthio camelus australis) than any other bird species included in this study. Notably, the H5N8 HPAI virus was detected in African penguins (Spheniscus demersus) in Namibia leading to the most severe mortality on record for this species in Namibia, with more than 350 
penguins dead [89]. Furthermore, the H5N1 HPAI virus was detected in Burkina Faso from hooded vultures (Necrosyrtes monachus) that exhibited dyspnea and neurological signs [69].

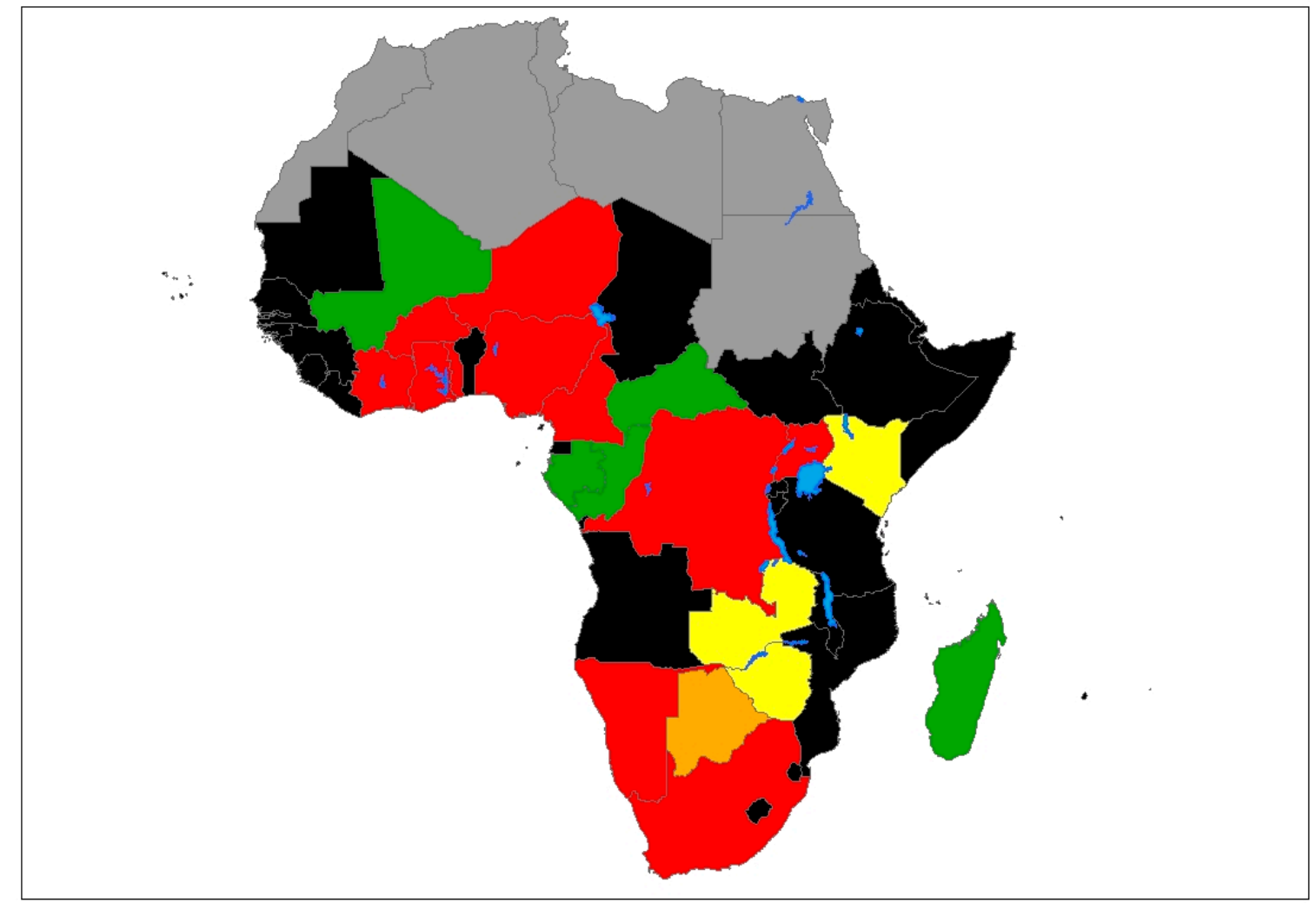

Figure 5. Geographical distribution of highly pathogenic avian influenza (HPAI) and low pathogenic avian influenza (LPAI) subtypes in sub-Saharan Africa. Color codes: red denotes countries reporting either HPAI only or both HPAI and LPAI; orange denotes countries reporting H5 or H7, but whose pathogenicity was not determined; yellow denotes countries reporting LPAI; green denotes countries reporting AIV whose subtypes and pathogenicity were not determined; black denotes countries in sub-Saharan Africa with no reports of AIV in birds in the study period; gray denotes North African countries not included in the study; blue denotes major water bodies.

H9N2, H3N8, H5N2, H7N7 and H6N2 LPAI viruses were also detected in domestic poultry. For example, H9N2 LPAI virus detected in Burkina Faso [91] and Ghana [41] and H6N2 LPAI virus in South Africa $[92,93]$ were from symptomatic poultry with signs of respiratory distress, decreased egg production and increased mortality, while in Kenya [64] and Nigeria [78,94] viruses with subtypes H9N2, H7N7, H5N2 and H3N8 were detected in asymptomatic birds. Moreover, mixed infection of H3N8 and H5N2 LPAI viruses was detected in apparently health turkeys (Meleagris Spp.) in Nigeria. Furthermore, H1N6, H3N6, H4N6, H4N8, H9N1 and H11N9 LPAI viruses were exclusively detected in wild birds.

\subsection{Distribution of AIVs among Different Avian Species}

The distribution of AIVs among different avian species according to the articles included in this review is depicted in Table 5. The majority of the studies were conducted in domestic birds with the highest number of studies (35) being in chicken (Gallus gallus) and (20) in domestic ducks (Anas platyrhynchos domestica) in 12 and 10 different countries, respectively (Table 5). Notably, studies in ostriches were reported only in South Africa [83,86,95-99]. In wild birds, most studies (6) were in Egyptian geese (Alopochen aegyptiacus) done in Kenya, South Africa and Zambia followed by 4 studies in unspecified wild birds. For the rest of the free-flying and aquatic birds, 1 to 3 studies were conducted in various sub-Saharan African countries as shown in Table 5. 
Table 5. Avian host range of AIV according to the 68 publications included in the review.

\begin{tabular}{|c|c|c|c|}
\hline Host & Number of Publications * & Number of Countries & Names of Countries \\
\hline \multicolumn{4}{|l|}{ Domestic Birds } \\
\hline Chicken & 35 & 12 & $\begin{array}{c}\text { Burkina Faso, Cameroon, Cote d'Ivoire, Ghana, Kenya, Madagascar, Mali, } \\
\text { Nigeria, South Africa, Togo, Uganda }\end{array}$ \\
\hline Domestic duck & 20 & 10 & $\begin{array}{r}\text { Cameroon, Cote d'Ivoire, DRC, Ghana, Kenya, Madagascar, Mali, Nigeria, } \\
\text { South Africa, Uganda }\end{array}$ \\
\hline Ostrich & 8 & 1 & South Africa \\
\hline Turkey & 7 & 7 & Cameroon, Cote d'Ivoire, Kenya, Mali, Nigeria, South Africa, Uganda \\
\hline Domestic guinea fowl & 7 & 5 & Burkina Faso, Cameroon, Mali, Nigeria, South Africa \\
\hline Pigeon & 5 & 3 & Cameroon, Nigeria, South Africa \\
\hline Domestic geese & 4 & 4 & Cameroon, Kenya, Madagascar, South Africa \\
\hline Poultry ${ }^{\mathrm{a}}$ & 3 & 3 & Nigeria \\
\hline Indian peafowl & 2 & 1 & Cameroon \\
\hline \multicolumn{4}{|l|}{ Wild Birds } \\
\hline Egyptian goose & 6 & 3 & Kenya, South Africa, Zambia \\
\hline Wild species ${ }^{a}$ & 4 & 3 & Nigeria, Africa, South Africa \\
\hline White-faced whistling duck & 3 & 3 & Kenya, Nigeria, Mali \\
\hline Yellow-billed duck & 3 & 2 & Kenya, South Africa \\
\hline Hooded vulture & 3 & 1 & Burkina Faso \\
\hline Red-billed quelea & 2 & 1 & Mali, Zimbabwe \\
\hline Red-billed teal & 2 & 1 & South Africa \\
\hline Great white pelican & 2 & 1 & Zambia \\
\hline Spur-winged goose & 2 & 1 & Nigeria \\
\hline Duck & 2 & 2 & Zambia, Zimbabwe \\
\hline Cattle egret & 2 & 2 & Nigeria, Zimbabwe \\
\hline Barn swallow & 2 & 1 & Zimbabwe \\
\hline African sacred ibis & 2 & 1 & South Africa \\
\hline Turtle dove & 2 & 1 & Cote d'Ivoire \\
\hline Cape teal & 2 & 2 & Kenya, South Africa \\
\hline African penguin $b$ & 1 & 1 & Namibia \\
\hline Sparrowhawk & 1 & 1 & Cote d'Ivoire \\
\hline Dove & 1 & 1 & Cote d'Ivoire \\
\hline Crow & 1 & 1 & Cote d'Ivoire \\
\hline Weaver & 1 & 1 & Cote d'Ivoire \\
\hline
\end{tabular}


Table 5. Cont.

\begin{tabular}{|c|c|c|c|}
\hline Host & Number of Publications * & Number of Countries & Names of Countries \\
\hline Hottentot teal & 1 & 1 & Kenya \\
\hline Red-knobbed coot & 1 & 1 & Kenya \\
\hline Garganey & 1 & 1 & Mali \\
\hline Ruff & 1 & 1 & Mali \\
\hline Northern pintail & 1 & 1 & Mali \\
\hline Purple swamphen & 1 & 1 & Mali \\
\hline Common moorhen & 1 & 1 & Mali \\
\hline Comb duck & 1 & 1 & Mali \\
\hline Gull-billed tern & 1 & 1 & Mali \\
\hline Spotted redshank & 1 & 1 & Mali \\
\hline Speckled pigeon & 1 & 1 & Nigeria \\
\hline Canada goose & 1 & 1 & Nigeria \\
\hline Gray crown crane & 1 & 1 & Nigeria \\
\hline African gray parrot & 1 & 1 & Nigeria \\
\hline Cape shoveler & 1 & 1 & South Africa \\
\hline Swift tern & 1 & 1 & South Africa \\
\hline White-winged black tern & 1 & 1 & South Africa \\
\hline Hadada ibis & 1 & 1 & South Africa \\
\hline Shelduck & 1 & 1 & South Africa \\
\hline Brown-throated martin & 1 & 1 & Kenya \\
\hline
\end{tabular}

${ }^{*}$ Multiple publications reported on multiple animal species; ${ }^{\text {a }}$ poultry and wild species not clearly specified; ${ }^{\mathrm{b}}$ sea bird; wild birds include free-flying wild birds and aquatic waterfowl. 


\section{Discussion}

This systematic review is aimed at investigating the prevalence, spatiotemporal distribution, and virus subtypes of AIVs detected in domestic and wild birds over a two-decade period (2000-2019) in sub-Saharan Africa. We retrieved many study articles from the databases, but only 68 studies from 22 different countries in sub-Saharan Africa met our inclusion criteria. Our findings showed a significant increase in the number of studies published between 2000 and 2019. This increase could be attributed to the increase in the number of AIV outbreaks recorded within the region, with Nigeria recording 1205 suspected outbreaks [100] between 2006 and 2007. Additionally, there has been an increase in surveillance studies $[49,51,66,67,85,98,101-104]$ regionally and in different countries, improved laboratory diagnostic capacity and generally enhanced surveillance systems aimed at preventing HPAI outbreaks.

The AIV prevalence generally varied from region to region with the highest prevalence being reported in Central Africa (7.1\%) and the lowest in East Africa (1.1\%) (Table 1). Moreover, our findings indicate that AIVs were detected throughout the year in sub-Saharan Africa with higher prevalence during the dry season. Whilst it is generally understood that the prevalence of AIV infection tends to increase during the period when Eurasian migratory water birds overwinter in sub-Saharan Africa and decrease after they migrate back to Eurasia [105], this study revealed a higher prevalence in the dry season when Eurasian migratory birds are absent or rare. It is possible that the limited water bodies in the dry season may allow increased interaction of waterfowl by congregating at particular sites, which provides opportunities for AIV transmission as well as detection during surveillance activities. However, despite the observed variations in prevalence and seasonality of AIV infection, the difference was not statistically significant. Further, the finding indicates that AIVs are perpetuated in migratory water birds originating from Eurasia as well as in indigenous African species that remain in the continent throughout the year.

Wild migratory aquatic birds are known to be the natural reservoir of AIVs globally [4,5]. Therefore, it is not surprising that different wild birds in sub-Saharan Africa harbor AIVs according to the findings of this review. Our findings also highlight the impact of AIVs on migratory and non-migratory local birds. Analysis of HA subtype diversity revealed that $\mathrm{H} 5$ was the most predominant HA subtype detected in this review followed by H9, H6 and H7. The predominance of these subtypes could be attributed to the fact that most of the AIV surveillance activities have concentrated on the detection of subtypes H5, H7 and/or H9 [106,107] and that they cause dramatic devastation, particularly HPAI that is difficult to miss. The $\mathrm{H} 5$ and $\mathrm{H} 7$ viruses were detected in both wild and domestic birds implying possible transmission from wild birds to domestic birds or vice versa.

The HA subtype diversity in our study has similarities and differences to that found in studies in China [107], Netherlands [108], North America [109,110], Germany [111] and Northern Europe [112] though a number of these studies were done in wild aquatic birds. For example, our study was comparable to the study in China [107] and that in the Netherlands [108], which did not detect H8, H12-H16. Furthermore, our study only detected six NA subtypes and 19 HA/NA combinations, while studies in Germany [111], Northern Europe [112] and North America [109,110] detected 40 or more subtype combinations. This higher subtype diversity in these studies could be because the surveillance was focused on wild waterfowl, which are expected to harbor a large pool of various AIV subtypes, which could also be true for Southern Africa, which had the highest subtype diversity in sub-Saharan Africa. The most prevalent NA subtype was N1, followed by N2 and N8, while N3-N5 and $\mathrm{H} 2, \mathrm{H} 8$ and H12-H16 were never detected, which may be due to limited surveillance efforts in wild birds or that there may be avian species-specific niches of certain HA and NA subtypes in the studied region.

Furthermore, the findings of this study revealed the presence of LPAI and HPAI viruses in both wild and domestic birds. However, the presence of HPAI viruses was more common among domestic birds, with the highest detection rate being in chickens and ducks. The dominant subtype was H5N1, which circulated in both wild and domestic birds. Our results further demonstrated that West African 
countries were the most hit by the H5N1 HPAI viruses with at least Nigeria [100,113], Niger [81], Ghana [81], Burkina Faso [69,113], Cote d'Ivoire [68] and Togo [71] recording one or more outbreaks during the evaluated period. This may be because West Africa is a major wintering area for migratory water birds (Anseriformes and Charadriiformes), which are the natural reservoirs of AIVs [5]. Moreover, the H5N1 HPAI viruses have persisted within the West African ecosystem since their introduction in Nigeria in 2006 [35,114]. The persistence and transmission of H5N1 HPAI viruses in West Africa have been attributed to the illegal movement of infected poultry and products, multispecies livestock farming and poor biosecurity compliance levels in live bird markets (LBMs) [35,115]. Furthermore, an HPAI outbreak caused by H5N1 viruses has been reported in Cameroon, a Central African country that shares borders with Nigeria, which suggests transboundary transmission due to porous borders, leading to illegal trade in livestock, especially birds, between these countries [58].

Apart from the H5N1 HPAI viruses, the study also revealed the presence of other HPAI virus subtypes namely H5N8 and H5N2 in different avian species in sub-Saharan Africa. The first case of H5N8 HPAI infection in Africa was reported around the same time in Egypt and Nigeria and later spread to other neighboring countries [52]. This outbreak spread to Uganda, South Africa, Zimbabwe and DRC [52,53,63,116,117]. Additionally, HPAI outbreaks caused by H5N2 viruses have been reported in farmed ostriches in South Africa. These outbreaks caused a devastating impact on the ostrich industry of South Africa, which account for at least 65\% of global ostrich production [118]. The presence and spread of H5N8 and H5N2 HPAI viruses have been attributed to migratory waterfowl due to the long-distance seasonal movements along their migration routes and also the other sedentary birds that have been implicated in facilitating the intracontinental dissemination of the virus [117]. In fact, H5N2 HPAI viruses have been detected in apparently healthy wild waterfowl in Nigeria [72]. Although HPAI viruses have been detected in many countries in sub-Saharan Africa, our results did not report any HPAI viruses in Zambia and Zimbabwe. Further, other countries such as Mali, Central Africa Republic, Congo-Brazzaville, Gabon and Madagascar did not specify the subtypes and pathogenicity of the viruses detected. However, the presence of HPAI viruses highlights the importance of continued and better epidemiological monitoring systems to allow their timely detection for mitigatory measures.

A large diversity of LPAI virus subtypes was detected in this review with H9N2 being the most predominant followed by H6N2 and H3N8. The H9N2 and H6N2 LPAI viruses were exclusively detected in domestic birds, in which they caused asymptomatic or symptomatic infections. Symptomatic infections caused by LPAI viruses include severe clinical signs in poultry, such as respiratory distress, intestinal signs and a drop in egg production [42]. These observations are consistent with previous studies in Iraq [119]. Moreover, H9N2 AIV infection is known to be endemic among poultry in Eurasia [120,121], and its circulation has been reported in North Africa, Europe and Asia among others [42,120-124]. H9N2 viruses are also known to circulate between wild birds and poultry sold at LBMs. LBMs are known to be reservoirs, amplifiers and sources of AIVs [46]. Furthermore, the transmission of H9N2 viruses from poultry to humans has been reported [125].

While H4N6 and H7N7 were the most prevalent AIV subtypes detected in Northern Europe and Germany [111,112], these subtypes were among the least detected in this review. H3N6 and H9N1 were the least and the only AIV subtypes detected in the great white pelican (Pelecanus onocrotalus) in Zambia [49,51]. Further, the presence of AIVs in wild waterfowl such as white-winged black terns (Chlidonias leucopterus), Egyptian geese (Alopochen aegyptiacus), yellow-billed duck (Anas undulata), shelduck (Tadoma cana) among others is important as these birds are known to be the primary reservoir of AIVs. Although our data seem to suggest an increase in the incidence of AIV infection in migratory waterfowl and domestic birds, this review also reports the detection of H5N1 HPAI viruses in African wild birds, hooded vultures (Necrosyrtes monachus) in Burkina Faso [69]. The detection of AIVs in wild migratory birds and minor bird reservoirs highlights the important role they play in the maintenance and transmission of these viruses. AIVs with $\mathrm{H} 5 \mathrm{Nx}, \mathrm{H} 7 \mathrm{Nx}$ and other subtypes (not fully identified) were detected in Afro-tropical waterfowl and swallows in Zimbabwe throughout the year, and the 
detection rate was higher when Palearctic birds were present, suggesting the yearly persistence of LPAI viruses in Afro-tropical waterfowl and other wild birds [126].

Although the benefits of systematic reviews are enormous, they are also not short of the challenges and limitations that come with aggregating data. For example, the distribution of AIV subtypes and avian species might not be limited to the present findings since our study included only publications with original data, well-elaborated methodological approach and laboratory-confirmed cases of AIVs. Furthermore, we only searched three recognized electronic databases and only included articles written in English, making it possible to leave out studies or publications that may be relevant to this review. Avian influenza subtypes depicted in this study may not be the true reflection of the subtype diversity in sub-Saharan Africa as some studies did not perform subtype identification due to insufficient samples and lack of laboratory capacity for influenza diagnostics.

\section{Conclusions}

Our review of AIVs in sub-Saharan Africa has provided an insight into the ecology and epidemiological trends of AIVs in birds over a twenty-year period (2000-2019). We found a considerable diversity of AIV subtypes in sub-Saharan Africa, with some subtypes being detected frequently in both wild and domestic birds. Furthermore, AIV was detected in wildfowl and domestic birds in both the wet and dry seasons, with viruses being detected in both Eurasian migratory and indigenous African wild birds. These results suggest a year-round perpetuation of AIVs in Afrotropical ecosystems, with seasonal variation. Continued surveillance, especially in wild birds, to better understand the eco-epidemiology of IAVs, along with improved biosecurity on poultry farms, enhanced extension services and engagement of various disciplines under a "One Health" approach in tackling avian influenza could assist in mitigating the impact of AIV in sub-Saharan Africa.

Supplementary Materials: The following are available online at http://www.mdpi.com/1999-4915/12/9/993/s1, S1 Checklist-PRISMA checklist. Table S1. References of all included studies. Table S2. Countries with reported AIV of diverse subtypes and avian species.

Author Contributions: Conceptualization, A.K. and E.S.; literature search and writing, A.K.; formal analysis, A.K. and P.N.; supervision: E.S., N.S. and A.T.; writing—original draft, A.K. and E.S.; writing-review and editing, E.S., N.S., A.T., M.K., H.S. and P.N. All authors read and approved the final version of the manuscript.

Funding: A.K. was supported by the Africa Center of Excellence for Infectious Disease of Humans and Animals (ACEIDHA) project (grant number P151847) funded by the World Bank. Funding was also provided in part by the Science and Technology Research Partnership for Sustainable Development (SATREPS) (JP19jm0110019) and the Japan Initiative for Global Research Network of Infectious Diseases (J-GRID) from Japan Agency for Medical Research and Development (AMED) (20wm0125008h0001).

Acknowledgments: We thank the University of Zambia, School of Veterinary Medicine, Department of Disease Control and the African Center of Excellence for Infectious Disease of Humans and Animals (ACEIDHA) for their support. We also thank Mukuma Lubinda from Macha Research Trust, Choma, Zambia for generating the map used in this study.

Conflicts of Interest: The authors declare no conflict of interest.

\section{References}

1. Peiris, J.S.; de Jong, M.D.; Guan, Y. Avian influenza virus (H5N1): A threat to human health. Clin. Microbiol. Rev. 2007, 20, 243-267. [CrossRef] [PubMed]

2. Abdelwhab, E.M.; Veits, J.; Mettenleiter, T.C. Prevalence and control of H7 avian influenza viruses in birds and humans. Epidemiol. Infect. 2014, 142, 896-920. [CrossRef] [PubMed]

3. Chowdhury, I.R.; Yeddula, S.G.R.; Kim, S.H. Pathogenicity and Transmissibility of North American H7 Low Pathogenic Avian Influenza Viruses in Chickens and Turkeys. Viruses 2019, 11, 163. [CrossRef] [PubMed]

4. Webster, R.G.; Bean, W.J.; Gorman, O.T.; Chambers, T.M.; Kawaoka, Y. Evolution and ecology of influenza A viruses. Microbiol. Rev. 1992, 56, 152-179. [CrossRef]

5. Olsen, B.; Munster, V.J.; Wallensten, A.; Waldenstrom, J.; Osterhaus, A.D.; Fouchier, R.A. Global patterns of influenza a virus in wild birds. Science 2006, 312, 384-388. [CrossRef] 
6. Landolt, G.A.; Olsen, C.W. Up to new tricks-A review of cross-species transmission of influenza A viruses. Anim. Health Res. Rev. 2007, 8, 1-21. [CrossRef]

7. Taubenberger, J.K.; Kash, J.C. Influenza virus evolution, host adaptation, and pandemic formation. Cell Host Microbe 2010, 7, 440-451. [CrossRef]

8. Tong, S.; Li, Y.; Rivailler, P.; Conrardy, C.; Castillo, D.A.; Chen, L.M.; Recuenco, S.; Ellison, J.A.; Davis, C.T.; York, I.A.; et al. A distinct lineage of influenza A virus from bats. Proc. Natl. Acad. Sci. USA 2012, 109, 4269-4274. [CrossRef]

9. Tong, S.; Zhu, X.; Li, Y.; Shi, M.; Zhang, J.; Bourgeois, M.; Yang, H.; Chen, X.; Recuenco, S.; Gomez, J.; et al. New world bats harbor diverse influenza A viruses. PLoS Pathog. 2013, 9, e1003657. [CrossRef]

10. Inglis, S.C.; Carroll, A.R.; Lamb, R.A.; Mahy, B.W.J. Polypeptides specified by the influenza virus genome: I. Evidence for eight distinct gene products specified by fowl plague virus. Virology 1976, 74, 489-503. [CrossRef]

11. Inglis, S.C.; McGeoch, D.J.; Mahy, B.W.J. Polypeptides specified by the influenza virus genome 2. Assignment of protein coding functions to individual genome segments by in vitro translation. Virology 1977, 78, 522-536. [CrossRef]

12. Lamb, R.A.; Choppin, P.W. Segment 8 of the influenza virus genome is unique in coding for two polypeptides. Proc. Natl. Acad. Sci. USA 1979, 76, 4908-4912. [CrossRef] [PubMed]

13. Lamb, R.A.; Choppin, P.W. Identification of a second protein (M2) encoded by RNA segment 7 of influenza virus. Virology 1981, 112, 729-737. [CrossRef]

14. Lamb, R.A.; Choppin, P.W.; Chanock, R.M.; Lai, C.J. Mapping of the two overlapping genes for polypeptides NS1 and NS2 on RNA segment 8 of influenza virus genome. Proc. Natl. Acad. Sci. USA 1980, 77, 1857-1861. [CrossRef] [PubMed]

15. Lamb, R.A.; Etkind, P.R.; Choppin, P.W. Evidence for a ninth influenza viral polypeptide. Virology 1978, 91, 60-78. [CrossRef]

16. Shih, S.-R.; Suen, P.-C.; Chen, Y.-S.; Chang, S.-C. A Novel Spliced Transcript of Influenza A/WSN/33 Virus. Virus Genes 1998, 17, 179-183. [CrossRef]

17. Chen, W.; Calvo, P.A.; Malide, D.; Gibbs, J.; Schubert, U.; Bacik, I.; Basta, S.; O’Neill, R.; Schickli, J.; Palese, P.; et al. A novel influenza A virus mitochondrial protein that induces cell death. Nat. Med. 2001, 7, 1306-1312. [CrossRef]

18. Wise, H.M.; Barbezange, C.; Jagger, B.W.; Dalton, R.M.; Gog, J.R.; Curran, M.D.; Taubenberger, J.K.; Anderson, E.C.; Digard, P. Overlapping signals for translational regulation and packaging of influenza A virus segment 2. Nucleic Acids Res. 2011, 39, 7775-7790. [CrossRef]

19. Wise, H.M.; Foeglein, A.; Sun, J.; Dalton, R.M.; Patel, S.; Howard, W.; Anderson, E.C.; Barclay, W.S.; Digard, P. A Complicated Message: Identification of a Novel PB1-Related Protein Translated from Influenza A Virus Segment 2 mRNA. J. Virol. 2009, 83, 8021-8031. [CrossRef]

20. Wise, H.M.; Hutchinson, E.C.; Jagger, B.W.; Stuart, A.D.; Kang, Z.H.; Robb, N.; Schwartzman, L.M.; Kash, J.C.; Fodor, E.; Firth, A.E.; et al. Identification of a Novel Splice Variant Form of the Influenza A Virus M2 Ion Channel with an Antigenically Distinct Ectodomain. PLoS Pathog. 2012, 8, e1002998. [CrossRef]

21. Selman, M.; Dankar, S.K.; Forbes, N.E.; Jia, J.-J.; Brown, E.G. Adaptive mutation in influenza A virus non-structural gene is linked to host switching and induces a novel protein by alternative splicing. Emerg. Microbes Infect. 2012, 1, 1-10. [CrossRef] [PubMed]

22. Muramoto, Y.; Noda, T.; Kawakami, E.; Akkina, R.; Kawaoka, Y. Identification of Novel Influenza A Virus Proteins Translated from PA mRNA. J. Virol. 2013, 87, 2455-2462. [CrossRef] [PubMed]

23. Yamayoshi, S.; Watanabe, M.; Goto, H.; Kawaoka, Y. Identification of a Novel Viral Protein Expressed from the PB2 Segment of Influenza A Virus. J. Virol. 2016, 90, 444-456. [CrossRef] [PubMed]

24. Jagger, B.W.; Wise, H.M.; Kash, J.C.; Walters, K.-A.; Wills, N.M.; Xiao, Y.-L.; Dunfee, R.L.; Schwartzman, L.M.; Ozinsky, A.; Bell, G.L.; et al. An Overlapping Protein-Coding Region in Influenza A Virus Segment 3 Modulates the Host Response. Science 2012, 337, 199-204. [CrossRef]

25. Okazaki, K.; Takada, A.; Ito, T.; Imai, M.; Takakuwa, H.; Hatta, M.; Ozaki, H.; Tanizaki, T.; Nagano, T.; Ninomiya, A.; et al. Precursor genes of future pandemic influenza viruses are perpetuated in ducks nesting in Siberia. Arch. Virol. 2000, 145, 885-893. [CrossRef] [PubMed] 
26. Wang, Q.; Ju, L.; Liu, P.; Zhou, J.; Lv, X.; Li, L.; Shen, H.; Su, H.; Jiang, L.; Jiang, Q. Serological and virological surveillance of avian influenza A virus H9N2 subtype in humans and poultry in Shanghai, China, between 2008 and 2010. Zoonoses Public Health 2015, 62, 131-140. [CrossRef] [PubMed]

27. Chang, D.; Zaia, J. Why Glycosylation Matters in Building a Better Flu Vaccine. Mol. Cell. Proteom. 2019, 18, 2348-2358. [CrossRef] [PubMed]

28. Kuchipudi, S.V.; Nissly, R.H. Novel Flu Viruses in Bats and Cattle: "Pushing the Envelope" of Influenza Infection. Vet. Sci. 2018, 5, 71. [CrossRef]

29. Webster, R.G.; Govorkova, E.A. Continuing challenges in influenza. Ann. N. Y. Acad. Sci. 2014, 1323, 115-139. [CrossRef]

30. Nao, N.; Yamagishi, J.; Miyamoto, H.; Igarashi, M.; Manzoor, R.; Ohnuma, A.; Tsuda, Y.; Furuyama, W.; Shigeno, A.; Kajihara, M.; et al. Genetic Predisposition To Acquire a Polybasic Cleavage Site for Highly Pathogenic Avian Influenza Virus Hemagglutinin. MBio 2017, 8. [CrossRef]

31. Alexander, D.J. An overview of the epidemiology of avian influenza. Vaccine 2007, 25, 5637-5644. [CrossRef] [PubMed]

32. Aly, M.M.; Arafa, A.; Hassan, M.K. Epidemiological findings of outbreaks of disease caused by highly pathogenic H5N1 avian influenza virus in poultry in Egypt during 2006. Avian Dis. 2008, 52, 269-277. [CrossRef] [PubMed]

33. Walsh, M.G.; Amstislavski, P.; Greene, A.; Haseeb, M.A. The Landscape Epidemiology of Seasonal Clustering of Highly Pathogenic Avian Influenza (H5N1) in Domestic Poultry in Africa, Europe and Asia. Transbound. Emerg. Dis. 2017, 64, 1465-1478. [CrossRef] [PubMed]

34. Duan, L.; Bahl, J.; Smith, G.J.; Wang, J.; Vijaykrishna, D.; Zhang, L.J.; Zhang, J.X.; Li, K.S.; Fan, X.H.; Cheung, C.L.; et al. The development and genetic diversity of H5N1 influenza virus in China, 1996-2006. Virology 2008, 380, 243-254. [CrossRef]

35. Fasanmi, O.G.; Odetokun, I.A.; Balogun, F.A.; Fasina, F.O. Public health concerns of highly pathogenic avian influenza H5N1 endemicity in Africa. Vet. World 2017, 10, 1194-1204. [CrossRef]

36. Kayali, G.; Kandeil, A.; El-Shesheny, R.; Kayed, A.S.; Maatouq, A.M.; Cai, Z.; McKenzie, P.P.; Webby, R.J.; El-Refaey, S.; Kandeel, A.; et al. Avian Influenza A(H5N1) Virus in Egypt. Emerg. Infect. Dis. 2016, 22, 379-388. [CrossRef]

37. Wang, X.; Jiang, H.; Wu, P.; Uyeki, T.M.; Feng, L.; Lai, S.; Wang, L.; Huo, X.; Xu, K.; Chen, E.; et al. Epidemiology of avian influenza A H7N9 virus in human beings across five epidemics in mainland China, 2013-2017: An epidemiological study of laboratory-confirmed case series. Lancet Infect. Dis. 2017, 17, 822-832. [CrossRef]

38. Zhang, Q.; Shi, J.; Deng, G.; Guo, J.; Zeng, X.; He, X.; Kong, H.; Gu, C.; Li, X.; Liu, J.; et al. H7N9 influenza viruses are transmissible in ferrets by respiratory droplet. Science 2013, 341, 410-414. [CrossRef]

39. Taubenberger, J.K.; Morens, D.M. Pandemic influenza-Including a risk assessment of H5N1. Rev. Sci. Tech. 2009, 28, 187-202. [CrossRef]

40. Kilbourne, E.D. Influenza pandemics of the 20th century. Emerg. Infect. Dis. 2006, 12, 9-14. [CrossRef]

41. Awuni, J.A.; Bianco, A.; Dogbey, O.J.; Fusaro, A.; Yingar, D.T.; Salviato, A.; Ababio, P.T.; Milani, A.; Bonfante, F.; Monne, I. Avian influenza H9N2 subtype in Ghana: Virus characterization and evidence of co-infection. Avian Pathol. 2019, 48, 470-476. [CrossRef]

42. El-Houadfi, M.; Fellahi, S.; Nassik, S.; Guerin, J.L.; Ducatez, M.F. First outbreaks and phylogenetic analyses of avian influenza H9N2 viruses isolated from poultry flocks in Morocco. Virol. J. 2016, 13, 140. [CrossRef]

43. You, L.; Diao, X. Assessing the Potential Impact of Avian Influenza on Poultry in West Africa: A Spatial Equilibrium Analysis. J. Agric. Econ. 2007, 58, 348-367. [CrossRef]

44. Sonaiya, E.B. Family poultry, food security and the impact of HPAI. Worlds Poult. Sci. J. 2019, 63, 132-138. [CrossRef]

45. Ofula, V.O.; Franklin, A.B.; Root, J.J.; Sullivan, H.J.; Gichuki, P.; Makio, A.; Bulimo, W.; Abong'o, B.O.; Muchai, M.; Schnabel, D. Detection of avian influenza viruses in wild waterbirds in the Rift Valley of Kenya using fecal sampling. Vector Borne Zoonotic Dis. 2013, 13, 394-400. [CrossRef]

46. Offeddu, V.; Cowling, B.J.; Peiris, J.S.M. Interventions in live poultry markets for the control of avian influenza: A systematic review. One Health 2016, 2, 55-64. [CrossRef] [PubMed]

47. Dodman, T. Waterbird Family Estimates in African Waterbird Population Estimates; Wetlands International: Wageningen, The Netherlands, 2006. 
48. Gaidet, N.; Dodman, T.; Caron, A.; Balanca, G.; Desvaux, S.; Goutard, F.; Cattoli, G.; Lamarque, F.; Hagemeijer, W.; Monicat, F. Avian influenza viruses in water birds, Africa. Emerg. Infect. Dis. 2007, 13, 626-629. [CrossRef] [PubMed]

49. Simulundu, E.; Mweene, A.S.; Tomabechi, D.; Hang'ombe, B.M.; Ishii, A.; Suzuki, Y.; Nakamura, I.; Sawa, H.; Sugimoto, C.; Ito, K.; et al. Characterization of H3N6 avian influenza virus isolated from a wild white pelican in Zambia. Arch. Virol. 2009, 154, 1517-1522. [CrossRef]

50. Abolnik, C. Avian Influenza in South Africa: A Review. In Proceedings of the 9th Annual Congress of the Southern African Society For Veterinary Epidemiology and Preventive Medicine, Pretoria, South Africa, 18-20 August 2010; pp. 36-43.

51. Simulundu, E.; Ishii, A.; Igarashi, M.; Mweene, A.S.; Suzuki, Y.; Hang'ombe, B.M.; Namangala, B.; Moonga, L.; Manzoor, R.; Ito, K.; et al. Characterization of influenza A viruses isolated from wild waterfowl in Zambia. J. Gen. Virol. 2011, 92, 1416-1427. [CrossRef]

52. Khomenko, S.; Abolnik, C.; Roberts, L.; Waller, L.; Shaw, K.; Monne, I.; Taylor, J.; Dhingra, M.; Claudia, P.; Mugyeom, M.; et al. 2016-2018 Spread of H5N8 highly pathogenic avian influenza (HPAI) in sub-Saharan Africa: Epidemiological and ecological observations. Focus 2018, 12, 1-20.

53. Twabela, A.T.; Tshilenge, G.M.; Sakoda, Y.; Okamatsu, M.; Bushu, E.; Kone, P.; Wiersma, L.; Zamperin, G.; Drago, A.; Zecchin, B.; et al. Highly Pathogenic Avian Influenza A(H5N8) Virus, Democratic Republic of the Congo, 2017. Emerg. Infect. Dis. 2018, 24, 1371-1374. [CrossRef] [PubMed]

54. Kouam, M.K.; Tchouankui, H.N.; Ngapagna, A.N. Epidemiological Features of Highly Pathogenic Avian Influenza in Cameroon. Vet. Med. Int. 2019, 2019, 3796369. [CrossRef] [PubMed]

55. Moher, D.; Liberati, A.; Tetzlaff, J.; Altman, D.G.; The PRISMA Group. Preferred reporting items for systematic reviews and meta-analyses: The PRISMA statement. Int. J. Surg. 2010, 8, 336-341. [CrossRef] [PubMed]

56. Letts, L.; Wilkins, S.; Law, M.; Stewart, D.; Bosch, J.; Westmorland, M. Critical Review form-Qualitative Studies (Version 2.0). 2007. Available online: https://www.unisa.edu.au/siteassets/episerver-6-files/global/ health/sansom/documents/icahe/cats/mcmasters_qualreview_version2-0.pdf (accessed on 25 March 2020).

57. Law, M.; Stewart, D.; Letts, L.; Pollock, N.; Bosch, J.; Westmorland, M. Guidelines for Critical Review of Qualitative Studies. McMaster Univ. Occup. Ther. Evid. Based Pract. Res. Group. 1998. Available online: https://srs-mcmaster.ca/wp-content/uploads/2015/05/Guidelines-for-Critical-Review-FormQuantitative-Studies.pdf (accessed on 25 March 2020).

58. Njouom, R.; Aubin, J.T.; Bella, A.L.; Demsa, B.M.; Rouquet, P.; Gake, B.; Ngangnou, A.; Foupouapouognigni, Y.; Van Der Werf, S.; Rocourt, J.; et al. Highly pathogenic avian influenza virus subtype H5N1 in ducks in the Northern part of Cameroon. Vet. Microbiol. 2008, 130, 380-384. [CrossRef]

59. Wade, A.; Jumbo, S.D.; Zecchin, B.; Fusaro, A.; Taiga, T.; Bianco, A.; Rodrigue, P.N.; Salomoni, A.; Kameni, J.M.F.; Zamperin, G.; et al. Highly Pathogenic Avian Influenza A(H5N8) Virus, Cameroon, 2017. Emerg. Infect. Dis. 2018, 24, 1367-1370. [CrossRef]

60. Wade, A.; Taiga, T.; Fouda, M.A.; MaiMoussa, A.; Marc, F.K.J.; Njouom, R.; Vernet, M.A.; Djonwe, G.; Mballa, E.; Kazi, J.P.; et al. Highly pathogenic avian influenza A/H5N1 Clade 2.3.2.1c virus in poultry in Cameroon, 2016-2017. Avian Pathol. 2018, 47, 559-575. [CrossRef]

61. Kirunda, H.; Erima, B.; Tumushabe, A.; Kiconco, J.; Tugume, T.; Mulei, S.; Mimbe, D.; Mworozi, E.; Bwogi, J.; Luswa, L.; et al. Prevalence of influenza A viruses in livestock and free-living waterfowl in Uganda. BMC Vet. Res. 2014, 10, 50. [CrossRef]

62. Munyua, P.M.; Githinji, J.W.; Waiboci, L.W.; Njagi, L.M.; Arunga, G.; Mwasi, L.; Mbabu, R.M.; Macharia, J.M.; Breiman, R.F.; Njenga, M.K.; et al. Detection of influenza A virus in live bird markets in Kenya, 2009-2011. Influenza Other Respir. Viruses 2013, 7, 113-119. [CrossRef]

63. Ndumu, D.; Zecchin, B.; Fusaro, A.; Arinaitwe, E.; Erechu, R.; Kidega, E.; Kayiwa, J.; Muwanga, E.; Kirumira, M.; Kirembe, G.; et al. Highly pathogenic avian influenza H5N8 Clade 2.3.4.4B virus in Uganda, 2017. Infect. Genet. Evol. 2018, 66, 269-271. [CrossRef]

64. Kariithi, H.M.; Welch, C.N.; Ferreira, H.L.; Pusch, E.A.; Ateya, L.O.; Binepal, Y.S.; Apopo, A.A.; Dulu, T.D.; Afonso, C.L.; Suarez, D.L. Genetic characterization and pathogenesis of the first H9N2 low pathogenic avian influenza viruses isolated from chickens in Kenyan live bird markets. Infect. Genet. Evol. 2019. [CrossRef]

65. Adamu, H.; Balami, A.; Abdu, P. Avian influenza, Gumboro and Newcastle disease antibodies and antigens in apparently healthy wild birds in Kano Metropolis, Nigeria. Niger. Vet. J. 2017, 38, 69-77. 
66. Cappelle, J.; de Almeida, R.S.; Fofana, B.; Dakouo, M.; Balanca, G.; Gil, P.; Albina, E.; Gaidet, N. Circulation of avian influenza viruses in wild birds in Inner Niger Delta, Mali. Influenza Other Respir. Viruses 2012, 6, 240-244. [CrossRef] [PubMed]

67. Coker, T.; Meseko, C.; Odaibo, G.; Olaleye, D. Circulation of the low pathogenic avian influenza subtype H5N2 virus in ducks at a live bird market in Ibadan, Nigeria. Infect. Dis. Poverty 2014, 3, 38. [CrossRef] [PubMed]

68. Couacy-Hymann, E.; Danho, T.; Keita, D.; Bodjo, S.C.; Kouakou, C.; Koffi, Y.M.; Beudje, F.; Tripodi, A.; de Benedictis, P.; Cattoli, G. The first specific detection of a highly pathogenic avian influenza virus (H5N1) in Ivory Coast. Zoonoses Public Health 2009, 56, 10-15. [CrossRef]

69. Ducatez, M.F.; Tarnagda, Z.; Tahita, M.C.; Sow, A.; de Landtsheer, S.; Londt, B.Z.; Brown, I.H.; Osterhaus, D.M.; Fouchier, R.A.; Ouedraogo, J.B.; et al. Genetic characterization of HPAI (H5N1) viruses from poultry and wild vultures, Burkina Faso. Emerg. Infect. Dis. 2007, 13, 611-613. [CrossRef]

70. Durosinlorun, A.; Umoh, J.U.; Abdu, P.A.; Ajogi, I. Serologic evidence of infection with H5 subtype influenza virus in apparently healthy local chickens in Kaduna State, Nigeria. Avian Dis. 2010, 54, 365-368. [CrossRef]

71. Fusade-Boyer, M.; Pato, P.S.; Komlan, M.; Dogno, K.; Jeevan, T.; Rubrum, A.; Kouakou, C.K.; Couacy-Hymann, E.; Batawui, D.; Go-Maro, E.; et al. Evolution of Highly Pathogenic Avian Influenza A(H5N1) Virus in Poultry, Togo, 2018. Emerg. Infect. Dis. 2019, 25, 2287-2289. [CrossRef]

72. Gaidet, N.; Cattoli, G.; Hammoumi, S.; Newman, S.H.; Hagemeijer, W.; Takekawa, J.Y.; Cappelle, J.; Dodman, T.; Joannis, T.; Gil, P.; et al. Evidence of infection by H5N2 highly pathogenic avian influenza viruses in healthy wild waterfowl. PLoS Pathog. 2008, 4, e1000127. [CrossRef]

73. Miko, R.; Abdu, P.; Assam, A.; Sai'du, L. Avian Influenza H5-Subtype Antibodies in Apparently Healthy Local Poultry in Live Bird Markets in Jigawa State, Nigeria. Bull. Anim. Health Prod. Afr. 2013, 61, 121-126.

74. Molia, S.; Samake, K.; Diarra, A.; Sidibe, M.S.; Doumbia, L.; Camara, S.; Kante, S.; Kamissoko, B.; Diakite, A.; Gil, P.; et al. Avian influenza and Newcastle disease in three risk areas for H5N1 highly pathogenic avian influenza in Mali, 2007-2008. Avian Dis. 2011, 55, 650-658. [CrossRef]

75. Molia, S.; Traore, A.; Gil, P.; Hammoumi, S.; Lesceu, S.; de Almeida, R.S.; Albina, E.; Chevalier, V. Avian influenza in backyard poultry of the Mopti region, Mali. Trop. Anim. Health Prod. 2010, 42, 807-809. [CrossRef] [PubMed]

76. Monne, I.; Joannis, T.M.; Fusaro, A.; De Benedictis, P.; Lombin, L.H.; Ularamu, H.; Egbuji, A.; Solomon, P.; Obi, T.U.; Cattoli, G.; et al. Reassortant avian influenza virus (H5N1) in poultry, Nigeria, 2007. Emerg. Infect. Dis. 2008, 14, 637-640. [CrossRef] [PubMed]

77. Nwankwo, I.O.; Faleke, O.O.; Garba, J. Avian influenza virus infection in apparently healthy domestic birds in Sokoto, Nigeria. Vet. Ital. 2012, 48, 309-312.

78. Oluwayelu, D.O.; Omolanwa, A.; Adebiyi, A.I.; Aiki-Raji, O.C. Flock-Based Surveillance for Low Pathogenic Avian Influenza Virus in Commercial Breeders and Layers, Southwest Nigeria. Afr. J. Infect. Dis. 2017, 11, 44-49. [CrossRef] [PubMed]

79. Owoade, A.A.; Gerloff, N.A.; Ducatez, M.F.; Taiwo, J.O.; Kremer, J.R.; Muller, C.P. Replacement of sublineages of avian influenza (H5N1) by reassortments, sub-Saharan Africa. Emerg. Infect. Dis. 2008, 14, 1731-1735. [CrossRef] [PubMed]

80. Snoeck, C.J.; Adeyanju, A.T.; De Landtsheer, S.; Ottosson, U.; Manu, S.; Hagemeijer, W.; Mundkur, T.; Muller, C.P. Reassortant low-pathogenic avian influenza H5N2 viruses in African wild birds. J. Gen. Virol. 2011, 92, 1172-1183. [CrossRef]

81. Tassoni, L.; Fusaro, A.; Milani, A.; Lemey, P.; Awuni, J.A.; Sedor, V.B.; Dogbey, O.; Commey, A.N.; Meseko, C.; Joannis, T.; et al. Genetically Different Highly Pathogenic Avian Influenza A(H5N1) Viruses in West Africa, 2015. Emerg. Infect. Dis. 2016, 22, 2132-2136. [CrossRef]

82. Abolnik, C.; Cornelius, E.; Bisschop, S.P.; Romito, M.; Verwoerd, D. Phylogenetic analyses of genes from South African LPAI viruses isolated in 2004 from wild aquatic birds suggests introduction by Eurasian migrants. Dev. Biol. 2006, 124, 189-199.

83. Abolnik, C.; Londt, B.Z.; Manvell, R.J.; Shell, W.; Banks, J.; Gerdes, G.H.; Akol, G.; Brown, I.H. Characterisation of a highly pathogenic influenza A virus of subtype H5N2 isolated from ostriches in South Africa in 2004. Influenza Other Respir. Viruses 2009, 3, 63-68. [CrossRef] 
84. Caron, A.; Chiweshe, N.; Mundava, J.; Abolnik, C.; Dondona, A.C.; Scacchia, M.; Gaidet, N. Avian Viral Pathogens in Swallows, Zimbabwe: Infectious Diseases in Hirundinidae: A Risk to Swallow? Ecohealth 2017, 14, 805-809. [CrossRef]

85. Caron, A.; Grosbois, V.; Etter, E.; Gaidet, N.; de Garine-Wichatitsky, M. Bridge hosts for avian influenza viruses at the wildlife/domestic interface: An eco-epidemiological framework implemented in southern Africa. Prev. Vet. Med. 2014, 117, 590-600. [CrossRef]

86. Howerth, E.W.; Olivier, A.; Franca, M.; Stallknecht, D.E.; Gers, S. Pathobiology of highly pathogenic avian influenza virus H5N2 infection in juvenile ostriches from South Africa. Avian Dis. 2012, 56, 966-968. [CrossRef] [PubMed]

87. Pfitzer, S.; Verwoerd, D.J.; Gerdes, G.H.; Labuschagne, A.E.; Erasmus, A.; Manvell, R.J.; Grund, C. Newcastle disease and avian influenza A virus in wild waterfowl in South Africa. Avian Dis. 2000, 44, 655-660. [CrossRef]

88. Poen, M.J.; Fouchier, R.A.M.; Webby, R.J.; Webster, R.G.; El-Zowalaty, M.E. Evidence of the Presence of Low Pathogenic Avian Influenza A Viruses in Wild Waterfowl in 2018 in South Africa. Pathogens 2019, 8, 163. [CrossRef] [PubMed]

89. Molini, U.; Aikukutu, G.; Roux, J.P.; Kemper, J.; Ntahonshikira, C.; Marruchella, G.; Khaiseb, S.; Cattoli, G.; Dundon, W.G. Avian Influenza H5N8 Outbreak in African Penguins (Spheniscus demersus), Namibia, 2019. J. Wildl. Dis. 2020, 56, 214-218. [CrossRef] [PubMed]

90. Andriamanivo, H.R.; Lancelot, R.; Maminiaina, O.F.; Rakotondrafara, T.F.; Jourdan, M.; Renard, J.F.; Gil, P.; de Almeida, R.S.; Albina, E.; Martinez, D.; et al. Risk factors for avian influenza and Newcastle disease in smallholder farming systems, Madagascar highlands. Prev. Vet. Med. 2012, 104, 114-124. [CrossRef]

91. Zecchin, B.; Minoungou, G.; Fusaro, A.; Moctar, S.; Ouedraogo-Kabore, A.; Schivo, A.; Salviato, A.; Marciano, S.; Monne, I. Influenza A (H9N2) Virus, Burkina Faso. Emerg. Infect. Dis. 2017, 23, 2118-2119. [CrossRef]

92. Abolnik, C.; Bisschop, S.P.; Gerdes, G.H.; Olivier, A.J.; Horner, R.F. Phylogenetic analysis of low-pathogenicity avian influenza H6N2 viruses from chicken outbreaks (2001-2005) suggest that they are reassortants of historic ostrich low-pathogenicity avian influenza H9N2 and H6N8 viruses. Avian Dis. 2007, 51, 279-284. [CrossRef]

93. Abolnik, C.; Strydom, C.; Rauff, D.L.; Wandrag, D.B.R.; Petty, D. Continuing evolution of H6N2 influenza a virus in South African chickens and the implications for diagnosis and control. BMC Vet. Res. 2019, 15, 455. [CrossRef]

94. Oluwayelu, D.O.; Aiki-Raji, C.O.; Adigun, O.T.; Olofintuyi, O.K.; Adebiyi, A.I. Serological Survey for Avian Influenza in Turkeys in Three States of Southwest Nigeria. Influenza Res. Treat. 2015, 2015, 787890. [CrossRef]

95. Abolnik, C. Evolution of $\mathrm{H} 5$ highly pathogenic avian influenza: Sequence data indicate stepwise changes in the cleavage site. Arch. Virol. 2017, 162, 2219-2230. [CrossRef] [PubMed]

96. Abolnik, C.; Gerdes, G.H.; Sinclair, M.; Ganzevoort, B.W.; Kitching, J.P.; Burger, C.E.; Romito, M.; Dreyer, M.; Swanepoel, S.; Cumming, G.S.; et al. Phylogenetic analysis of influenza A viruses (H6N8, H1N8, H4N2, H9N2, H10N7) isolated from wild birds, ducks, and ostriches in South Africa from 2007 to 2009. Avian Dis. 2010, 54, 313-322. [CrossRef] [PubMed]

97. Abolnik, C.; Olivier, A.; Reynolds, C.; Henry, D.; Cumming, G.; Rauff, D.; Romito, M.; Petty, D.; Falch, C. Susceptibility and Status of Avian Influenza in Ostriches. Avian Dis. 2016, 60, 286-295. [CrossRef]

98. Abolnik, C.; Olivier, A.J.; Grewar, J.; Gers, S.; Romito, M. Molecular analysis of the 2011 HPAI H5N2 outbreak in ostriches, South Africa. Avian Dis. 2012, 56, 865-879. [CrossRef] [PubMed]

99. Sinclair, M.; Bruckner, G.K.; Kotze, J.J. Avian influenza in ostriches: Epidemiological investigation in the Western Cape Province of South Africa. Vet. Ital. 2006, 42, 69-76. [PubMed]

100. Fasina, F.O.; Bisschop, S.P.; Joannis, T.M.; Lombin, L.H.; Abolnik, C. Molecular characterization and epidemiology of the highly pathogenic avian influenza H5N1 in Nigeria. Epidemiol. Infect. 2009, 137, 456-463. [CrossRef]

101. Couacy-Hymann, E.; Kouakou, A.V.; Kouame, C.K.; Kouassi, A.L.; Koffi, Y.M.; Godji, P.; Nana, P.; Tarnagda, Z.; Akoua-Koffi, C. Surveillance for avian influenza and Newcastle disease in backyard poultry flocks in Cote d'Ivoire, 2007-2009. Rev. Sci. Tech. 2012, 31, 821-828. [CrossRef]

102. Cumming, G.S.; Caron, A.; Abolnik, C.; Cattoli, G.; Bruinzeel, L.W.; Burger, C.E.; Cecchettin, K.; Chiweshe, N.; Mochotlhoane, B.; Mutumi, G.L.; et al. The ecology of influenza A viruses in wild birds in southern Africa. Ecohealth 2011, 8, 4-13. [CrossRef] 
103. Fuller, T.L.; Ducatez, M.F.; Njabo, K.Y.; Couacy-Hymann, E.; Chasar, A.; Aplogan, G.L.; Lao, S.; Awoume, F.; Tehou, A.; Langeois, Q.; et al. Avian influenza surveillance in Central and West Africa, 2010-2014. Epidemiol. Infect. 2015, 143, 2205-2212. [CrossRef]

104. Kim, H.K.; Jeong, D.G.; Yoon, S.W. Recent outbreaks of highly pathogenic avian influenza viruses in South Korea. Clin. Exp. Vaccine Res. 2017, 6, 95-103. [CrossRef]

105. Gaidet, N.; Caron, A.; Cappelle, J.; Cumming, G.S.; Balanca, G.; Hammoumi, S.; Cattoli, G.; Abolnik, C.; de Almeida, R.S.; Gil, P.; et al. Understanding the ecological drivers of avian influenza virus infection in wildfowl: A continental-scale study across Africa. Proc. Biol. Sci. 2012, 279, 1131-1141. [CrossRef] [PubMed]

106. Naguib, M.M.; Verhagen, J.H.; Samy, A.; Eriksson, P.; Fife, M.; Lundkvist, A.; Ellstrom, P.; Jarhult, J.D. Avian influenza viruses at the wild-domestic bird interface in Egypt. Infect. Ecol. Epidemiol. 2019, 9, 1575687. [CrossRef] [PubMed]

107. Chen, X.; Li, C.; Sun, H.T.; Ma, J.; Qi, Y.; Qin, S.Y. Prevalence of avian influenza viruses and their associated antibodies in wild birds in China: A systematic review and meta-analysis. Microb. Pathog. 2019, 135, 103613. [CrossRef] [PubMed]

108. Bergervoet, S.A.; Pritz-Verschuren, S.B.E.; Gonzales, J.L.; Bossers, A.; Poen, M.J.; Dutta, J.; Khan, Z.; Kriti, D.; van Bakel, H.; Bouwstra, R.; et al. Circulation of low pathogenic avian influenza (LPAI) viruses in wild birds and poultry in the Netherlands, 2006-2016. Sci. Rep. 2019, 9, 13681. [CrossRef] [PubMed]

109. Diskin, E.R.; Friedman, K.; Krauss, S.; Nolting, J.M.; Poulson, R.L.; Slemons, R.D.; Stallknecht, D.E.; Webster, R.G.; Bowman, A.S. Subtype Diversity of Influenza A Virus in North American Waterfowl: A Multidecade Study. J. Virol. 2020, 94. [CrossRef] [PubMed]

110. Krauss, S.; Walker, D.; Pryor, S.P.; Niles, L.; Chenghong, L.; Hinshaw, V.S.; Webster, R.G. Influenza A viruses of migrating wild aquatic birds in North America. Vector Borne Zoonotic Dis. 2004, 4, 177-189. [CrossRef]

111. Suss, J.; Schafer, J.; Sinnecker, H.; Webster, R.G. Influenza virus subtypes in aquatic birds of eastern Germany. Arch. Virol. 1994, 135, 101-114. [CrossRef]

112. Wallensten, A.; Munster, V.J.; Latorre-Margalef, N.; Brytting, M.; Elmberg, J.; Fouchier, R.A.; Fransson, T.; Haemig, P.D.; Karlsson, M.; Lundkvist, A.; et al. Surveillance of influenza A virus in migratory waterfowl in northern Europe. Emerg. Infect. Dis. 2007, 13, 404-411. [CrossRef]

113. Ducatez, M.F.; Olinger, C.M.; Owoade, A.A.; Tarnagda, Z.; Tahita, M.C.; Sow, A.; De Landtsheer, S.; Ammerlaan, W.; Ouedraogo, J.B.; Osterhaus, A.D.; et al. Molecular and antigenic evolution and geographical spread of H5N1 highly pathogenic avian influenza viruses in western Africa. J. Gen. Virol. 2007, 88, 2297-2306. [CrossRef]

114. Joannis, T.; Lombin, L.H.; De Benedictis, P.; Cattoli, G.; Capua, I. Confirmation of H5N1 avian influenza in Africa. Vet. Rec. 2006, 158, 309-310. [CrossRef]

115. Fasanmi, O.G.; Ahmed, S.S.U.; Oladele-Bukola, M.O.; El-Tahawy, A.S.; Elbestawy, A.R.; Fasina, F.O. An evaluation of biosecurity compliance levels and assessment of associated risk factors for highly pathogenic avian influenza H5N1 infection of live-bird-markets, Nigeria and Egypt. Acta Trop. 2016, 164, 321-328. [CrossRef] [PubMed]

116. Abolnik, C.; Pieterse, R.; Peyrot, B.M.; Choma, P.; Phiri, T.P.; Ebersohn, K.; Heerden, C.J.V.; Vorster, A.A.; Zel, G.V.; Geertsma, P.J.; et al. The Incursion and Spread of Highly Pathogenic Avian Influenza H5N8 Clade 2.3.4.4 Within South Africa. Avian Dis. 2019, 63, 149-156. [CrossRef] [PubMed]

117. Twabela, A.T.; Okamatsu, M.; Tshilenge, G.M.; Mpiana, S.; Masumu, J.; Nguyen, L.T.; Matsuno, K.; Monne, I.; Zecchin, B.; Sakoda, Y. Molecular, antigenic, and pathogenic characterization of H5N8 highly pathogenic avian influenza viruses isolated in the Democratic Republic of Congo in 2017. Arch. Virol. 2020, 165, 87-96. [CrossRef] [PubMed]

118. Abolnik, C.; Fehrsen, J.; Olivier, A.; van Wyngaardt, W.; Fosgate, G.; Ellis, C. Serological investigation of highly pathogenic avian influenza H5N2 in ostriches (Struthio camelus). Avian Pathol. 2013, 42, $206-214$. [CrossRef] [PubMed]

119. Khamas, E.J. Avian influenza (H9N2) outbreak in Iraq. Iraqi J. Vet. Med. 2008, 32, 223-230.

120. Lindh, E.; Ek-Kommonen, C.; Vaananen, V.M.; Vaheri, A.; Vapalahti, O.; Huovilainen, A. Molecular epidemiology of H9N2 influenza viruses in Northern Europe. Vet. Microbiol. 2014, 172, 548-554. [CrossRef]

121. Monne, I.; Hussein, H.A.; Fusaro, A.; Valastro, V.; Hamoud, M.M.; Khalefa, R.A.; Dardir, S.N.; Radwan, M.I.; Capua, I.; Cattoli, G. H9N2 influenza A virus circulates in H5N1 endemically infected poultry population in Egypt. Influenza Other Respir. Viruses 2013, 7, 240-243. [CrossRef] 
122. Ali, M.; Yaqub, T.; Mukhtar, N.; Imran, M.; Ghafoor, A.; Shahid, M.F.; Yaqub, S.; Smith, G.J.D.; Su, Y.C.F.; Naeem, M. Prevalence and Phylogenetics of H9n2 in Backyard and Commercial Poultry in Pakistan. Avian Dis. 2018, 62, 416-424. [CrossRef]

123. Youk, S.S.; Lee, D.H.; Jeong, J.H.; Pantin-Jackwood, M.J.; Song, C.S.; Swayne, D.E. Live bird markets as evolutionary epicentres of H9N2 low pathogenicity avian influenza viruses in Korea. Emerg. Microbes Infect. 2020, 9, 616-627. [CrossRef]

124. Zhu, R.; Xu, D.; Yang, X.; Zhang, J.; Wang, S.; Shi, H.; Liu, X. Genetic and biological characterization of H9N2 avian influenza viruses isolated in China from 2011 to 2014. PLoS ONE 2018, 13, e0199260. [CrossRef]

125. Peiris, M.; Yuen, K.Y.; Leung, C.W.; Chan, K.H.; Ip, P.L.; Lai, R.W.; Orr, W.K.; Shortridge, K.F. Human infection with influenza H9N2. Lancet 1999, 354, 916-917. [CrossRef]

126. Caron, A.; Abolnik, C.; Mundava, J.; Gaidet, N.; Burger, C.E.; Mochotlhoane, B.; Bruinzeel, L.; Chiweshe, N.; de Garine-Wichatitsky, M.; Cumming, G.S. Persistence of low pathogenic avian influenza virus in waterfowl in a Southern African ecosystem. Ecohealth 2011, 8, 109-115. [CrossRef] [PubMed]

(C) 2020 by the authors. Licensee MDPI, Basel, Switzerland. This article is an open access article distributed under the terms and conditions of the Creative Commons Attribution (CC BY) license (http://creativecommons.org/licenses/by/4.0/). 